BRIEF

\title{
Prevalence of Diabetes on Santa Cruz Island in Galapagos Archipelago
}

\author{
Nicola Tufton, MBBS, BSc; Tahseen Chowdhury, MD
}

Suggested citation for this article: Tufton N, Chowdhury T. Prevalence of Diabetes on Santa Cruz Island in Galapagos Archipelago. Prev Chronic Dis 2015;12:150108. DOI: http:// dx.doi.org/10.5888/pcd12.150108.

\section{PEER REVIEWED}

\section{Abstract}

This was an observational study offering a screening program for diabetes in a health clinic in Puerto Ayora town on Santa Cruz Island to determine the prevalence of this disorder and identify those at risk. A 1-month screening program was undertaken. Of 141 patients screened, $85 \%$ of men and $83 \%$ of women were overweight or obese; $16(11 \%)$ had suspected undiagnosed diabetes and 22 $(16 \%)$ were at high risk of developing diabetes. This is the first reported study of glucose intolerance prevalence in Galapagos. Urgent education and prevention programs are required to address this public health problem.

\section{Objective}

Diabetes mellitus is an increasing health problem, imposing a public health burden on health systems worldwide (1). The International Diabetes Federation (IDF) reports a prevalence of $6 \%$ ( 1 in 18 adults) in Ecuador and US $\$ 562.50$ annual health care expenditure per person (2).

The onset of type 2 diabetes can be delayed or prevented; effective management reduces risk of complications. Self-management is the cornerstone of effective care (3). Our study was observational and offered a screening and education program for diabetes in a health clinic in the town of Puerto Ayora to determine prevalence of this disorder and identify those at risk.

\section{Methods}

The Galapagos archipelago, with a population of approximately 23,000 (48.2\% female), is $1,000 \mathrm{~km}$ (621 miles) off Ecuador's coast. It consists of 20 islands ( 5 of which are inhabited) and 250 islets (4). Santa Cruz is the main island and has $61 \%$ of the population (approximately 14,000); $78 \%$ of the population live in the main town, Puerto Ayora. The age structure of the population on the island consists of $28 \%$ aged less than 15 years, $68 \%$ aged 15 to 64 years, and $4 \%$ aged 65 years or older(5).

Between October 31 and November 29, 2012, a diabetes screening program was offered in the Centro de Salud clinic in Puerto Ayora. The diabetes screening program was advertised weekly on the local television news channel, radio station, and on the Internet. For 1 day (November 14, 2012, National Diabetes Day) screening was offered at a stall set up in the local park by the port.

The International Expert Committee guidelines for diagnosis were used: fasting glucose $126 \mathrm{mg} / \mathrm{dL}$ or higher $(\geq 7 \mathrm{mmol} / \mathrm{L}$ ) for diagnosing diabetes and fasting glucose 100 to $125 \mathrm{mg} / \mathrm{dL}$ (5.6-6.9 $\mathrm{mmol} / \mathrm{L}$ ) for diagnosing high-risk individuals with impaired fasting glucose (IFG) $(1,6)$. The committee's guidelines define highrisk individuals as adults whose body mass index (BMI) is $25 \mathrm{~kg}$ / $\mathrm{m}^{2}$ or higher with 1 or more of the following risk factors: physical inactivity, first-degree relative with diabetes, high risk race/ethnicity (African American, Latino, Native American, Asian American, Pacific Islander), hypertension 140/90 $\mathrm{mm} \mathrm{Hg}$ or higher or undergoing therapy for hypertension, and history of cardiovascular disease. We used capillary blood glucose testing on a single finger prick test (7-9).

At presentation to the health clinic, data on the following personal demographics and physical measurements were collected: age, smoking status, personal history of diabetes, weight, height, fasting capillary glucose, and blood pressure. Glucose was tested with Contour test stripes using a Contour (Bayer) glucometer. Weight was measured on a Weigh Beam Eye-Level (Detecto Scale Company) scale $(0-175 \mathrm{~kg}$ or $0-400 \mathrm{lb})$.

All patients were provided with education on nutrition and lifestyle changes. Patients with abnormal results were given advice about health concerns and information about improving their diet and increasing physical activity. Appointments were made for repeat testing within 1 to 2 weeks. 


\section{Results}

From 5 to 15 patients, including pediatric patients, presented themselves each day to the clinic for various health reasons and were invited to participate in the screening program. Patients were excluded if under the age of 18 years, pregnant, or had not fasted. In total, 141 patients were screened for fasting glucose, and 135 had their weight measured. Six patients refused to have their weight measured or were unable to be weighed (eg, in a wheelchair).

Among those screened, 59.6\% were women, and ages ranged from 20 to 78 years (mean, 46 y) (Table 1). Eighty women and 55 men agreed to have their weight measured, and weights ranged from 45 to $120 \mathrm{~kg}\left(\mathrm{BMI}, 20-44 \mathrm{~kg} / \mathrm{m}^{2}\right.$ ) for women and 58 to $120 \mathrm{~kg}$ (BMI $23-39 \mathrm{~kg} / \mathrm{m}^{2}$ ) for men; $41.8 \%$ of men and $45.0 \%$ of women were overweight (BMI $25-29.9 \mathrm{~kg} / \mathrm{m}^{2}$ ), and $43.6 \%$ men and $37.5 \%$ of women were obese (BMI $\left.\geq 30 \mathrm{~kg} / \mathrm{m}^{2}\right)$. Fasting capillary glucose varied widely, ranging from 51 to $346 \mathrm{mg} / \mathrm{dL}$.

Of the 141 patients screened, $23(16.3 \%)$ reported that they had previously been told they have diabetes. Of these, 9 were taking at least 1 medication: 6 were taking metformin; 1 , sitagliptin; 1 , glimepiride; and 2, glibenclamide. No patients were having regular follow-up on the mainland.

Among patients who were not known to have diabetes, 16 had raised fasting glucose levels; 22 patients had IFG (Table 2). Therefore, within this screened population, $11.3 \%$ had a likely new diagnosis of diabetes and $15.6 \%$ were at high risk of developing diabetes in the future.

\section{Discussion}

Our findings suggest substantial numbers of people have undiagnosed, or are at high risk of developing, diabetes. These figures appear higher than those reported by IDF and World Health Organization for Ecuador, especially for the prevalence of obesity $(2,10)$ (Appendix A). Obesity is strongly linked with diabetes risk (11). No published data was found on rates of exercise or hypertension in Galapagos.

Ecuador has close ties to the United States and may be sensitive to US economic, industrial, and cultural influences (12). Galapagos is heavily reliant on tourism, and with an annual population growth of $6.4 \%$, may be at higher risk of increasing obesity (4). Landscape on the islands is not amenable to farming, and farming is carefully managed to protect endemic species. Similar situations have been noted in other island populations, such as the $\mathrm{Pa}$ cific islands, with increasing prevalence of diabetes and obesity due to rapid population and economic growth and transition to westernization (13). Appendix B shows a comparison of data for diabetes and obesity for Ecuador and other island populations.

Limitations of this study are that it has a small sample size and high dropout rate for repeat checks. Caution should be used when extrapolating outside this population. Bias in sampling may have occurred because only those individuals motivated to seek health advice were screened. Our study may overestimate the prevalence of obesity, as it is unlikely to have data on the more physically active, such as fishermen or cruise ship employees.

Individuals with impaired fasting glucose or impaired glucose tolerance are at high risk for developing diabetes. For populations like that of the Galapagos Islands, which already has multiple risk factors for poor health, there is an urgent need for action. President Rafael Correa suggested introducing a new tax on junk food suppliers to try to address Ecuador's rapidly rising obesity rates (14).

\section{Acknowledgments}

No financial support was received for this work.

\section{Author Information}

Corresponding Author: Nicola Tufton, MBBS, BSc, Department of Diabetes and Metabolism, Diabetes Centre, Homerton Hospital, Homerton Row, London, United Kingdom, E9 6SR. Telephone: 0208510 7647. Email: nicola.tufton1@nhs.net.

Author Affiliation: Tahseen Chowdhury, Royal London Hospital, BartsHealth NHS Trust, London, United Kingdom.

\section{References}

1. American Diabetes Association. Standards of medical care in diabetes - 2013. Diabetes Care 2013;36(Suppl 1):S11-66.

2. International Diabetes Federation. IDF diabetes atlas, 6th edition. Brussels (BE): International Diabetes Federation, 2013. http://www.idf.org/diabetesatlas. Accessed March 22, 2015.

3. Department of Health. National Service Framework for diabetes: standards. 2001. http://www.gov.uk/government/ uploads/system/uploads/attachment_data/file/198836/ National_Service_Framework_for_Diabetes.pdf. Accessed August 2013.

4. León MG, Salazar GC. Population and migration in Galapagos. In: Galapagos report 2011-2012. Puerto Ayora, Galapagos (EC): GNPS, GCREG, CDF, and GC; 2013. p. 44-51.

\footnotetext{
The opinions expressed by authors contributing to this journal do not necessarily reflect the opinions of the U.S. Department of Health and Human Services, the Public Health Service, the Centers for Disease Control and Prevention, or the authors' affiliated institutions.
} 
5. Fascículo Provincial Galápagos. Resultados del censo 2010de población y vivienda en el Ecuador. Instituto Nacional de Estadística y Censos. http://www.ecuadorencifras.gob.ec/wpcontent/descargas/Manu-lateral/Resultados-provinciales/ galapagos.pdf. Accessed May 16, 2015.

6. International Expert Committee. International Expert Committee report on the role of the $\mathrm{A} 1 \mathrm{C}$ assay in the diagnosis of diabetes. Diabetes Care 2009;32(7):1327-34.

7. Zhou X, Pang Z, Gao W, Wang S, Zhang L, Ning F, et al. Performance of an $\mathrm{A} 1 \mathrm{C}$ and fasting capillary blood glucose test for screening newly diagnosed diabetes and pre-diabetes defined by an oral glucose tolerance test in Qingdao, China. Diabetes Care 2010;33(3):545-50.

8. Toscano CM, Duncan BB, Mengue SS, Polanczyk CA, Nucci LB, Costa e Forti A, et al. Initial impact and cost of a nationwide population screening campaign for diabetes in Brazil: a follow up study. BMC Health Serv Res 2008; 8(1):189.

9. Spijkerman AM, Adriaanse MC, Dekker JM, Nijpels G, Stehouwer CD, Bouter LM, et al. Diabetic patients detected by population-based stepwise screening already have a diabetic cardiovascular risk profile. Diabetes Care 2002;25(10):1784-9.

10. World Health Organization. Global Health Observatory (GHO) data. http://www.who.int/gho/ncd/risk_factors/en/. Accessed March 22, 2015.

11. Amos AF, McCarty DJ, Zimmet P. The rising global burden of diabetes and its complications: estimates and projections to the year 2010. Diabet Med 1997;14(Suppl 5):S1-85.

12. Bernstein A. Emerging patterns in overweight and obesity in Ecuador. Rev Panam Salud Publica 2008;24(1):71-4.

13. Hosey G, Aitaoto N, Satterfield D, Kelly J, Apaisam CJ, Belyeu-Camacho T, et al. The culture, community, and science of type 2 diabetes prevention in the US Associated Pacific Islands. Prev Chronic Dis 2009;6(3):A104. Erratum in: Prev Chronic Dis 2011;8(1):A28. http://www.cdc.gov/pcd/issues/ 2009/jul/08_0129.htm. Accessed March 22, 2015.

14. Tegel S. Ecuador to tax fast food in effort to halt soaring obesity rate. The Independent. 2014Sept 11.

The opinions expressed by authors contributing to this journal do not necessarily reflect the opinions of the U.S. Department of Health and Human Services, the Public Health Service, the Centers for Disease Control and Prevention, or the authors' affiliated institutions. 


\section{Tables}

Table 1. Demographics of Patients and Fasting Glucose Readings, Puerto Ayora, Galapagos, Ecuador, 2012

\begin{tabular}{|c|c|c|c|c|c|c|c|}
\hline Statistic & Age, $y$ & $\begin{array}{c}\text { Fasting } \\
\text { Glucose, } \mathrm{mg} / \mathrm{dL} \\
(\mathrm{n}=141)\end{array}$ & $\begin{array}{l}\text { Fasting } \\
\text { Glucose, } \\
\mathrm{mmol} / \mathrm{L}(\mathrm{n}= \\
141)\end{array}$ & \multicolumn{2}{|c|}{ Weight $^{a}$} & \multicolumn{2}{|c|}{ Body Mass Index } \\
\hline Range & $20-78$ & $51-346$ & $2.83-19.2$ & $45-120$ & $58-120$ & $20-44$ & $23-39$ \\
\hline Median & 44 & 96 & 5.3 & 65 & 80 & 29 & 28 \\
\hline
\end{tabular}

a 135 patients had weight measured; 6 patients either refused to be weighed or could not be weighed (eg, in wheelchair, wearing plaster cast). 
Table 2. Fasting Capillary Glucose Readings ( $\mathrm{N}=141)$, Puerto Ayora, Galapagos, Ecuador, 2012

\begin{tabular}{|l|r|r|r|r|r|}
\hline $\begin{array}{l}\text { Capillary Glucose } \\
\text { Readings }\end{array}$ & $\mathrm{N} \mathrm{( \% )}$ & $\begin{array}{c}\text { No. (\%) With Known } \\
\text { Diabetes Mellitus }\end{array}$ & $\begin{array}{c}\text { No. (\%) With } \\
\text { Suspected New } \\
\text { Diagnosis of } \\
\text { Diabetes Mellitus }\end{array}$ & $\begin{array}{r}\text { No. (\%) Men With } \\
\text { Suspected New } \\
\text { Diagnosis of Diabetes } \\
\text { Mellitus }^{\text {a }}\end{array}$ & $\begin{array}{c}\text { No. (\%) Women With } \\
\text { Suspected New } \\
\text { Diagnosis of Diabetes } \\
\text { Mellitus }^{\text {a }}\end{array}$ \\
\hline$\geq 7.0 \mathrm{mmol} / \mathrm{L}$ & $30(21.3)$ & $14(9.9)$ & $16(11.3)$ & $5(31)$ & $11(69)$ \\
\hline $5.6-6.9 \mathrm{mmol} / \mathrm{L}$ & $26(18.4)$ & $4(2.8)$ & $22(15.6)$ & $12(45)$ & $12(55)$ \\
\hline
\end{tabular}

a Based on only 1 fasting reading. 


\section{Appendix A. Prevalence Data for Obesity and Diabetes for Ecuador}

\begin{tabular}{|c|c|c|c|}
\hline \multirow[b]{2}{*}{ Characteristic } & \multicolumn{2}{|c|}{ World Health Organization (10) } & \multirow{2}{*}{$\begin{array}{l}\text { International Diabetes } \\
\text { Federation (2) }\end{array}$} \\
\hline & Men & Women & \\
\hline Diabetes & $8.7 \%$ & $9.4 \%$ & $5.9 \%$ \\
\hline Overweight (body mass index $>25 \mathrm{~kg} / \mathrm{m}^{2}$ ) & $51.8 \%$ & $60.2 \%$ & \multirow{2}{*}{ NA } \\
\hline Obese (body mass index $>30 \mathrm{~kg} / \mathrm{m}^{2}$ ) & $15.7 \%$ & $28.2 \%$ & \\
\hline
\end{tabular}

Abbreviation: NA, not available. 


\section{Appendix B. Prevalence of Diabetes and Obesity Across Various Island Populations}

\begin{tabular}{|c|c|c|c|c|}
\hline \multirow[b]{2}{*}{ Location } & \multirow[b]{2}{*}{ Population } & \multirow{2}{*}{$\begin{array}{c}\text { Prevalence of Diabetes, } \\
\%\end{array}$} & \multicolumn{2}{|c|}{$\begin{array}{l}\text { Prevalence of Overweight and Obesity (BMI >25 } \\
\left.\qquad \mathrm{kg} / \mathrm{m}^{2}\right), \%\end{array}$} \\
\hline & & & Men & Women \\
\hline Santa Cruz & 14,000 & $11^{a}$ & NA & NA \\
\hline Republic of Palau & 13,000 & $18-38.9^{b, c}$ & $81.9^{d}$ & $81.7^{d}$ \\
\hline $\begin{array}{l}\text { Federated States of } \\
\text { Micronesia }\end{array}$ & 54,000 & $24.4-36.6^{c, d}$ & $71.4^{\mathrm{d}}$ & $82.5^{d}$ \\
\hline American Samoa & 97,000 & $47.3^{b}$ & $82.6^{d}$ & $88.9^{d}$ \\
\hline Guam & 107,000 & $11-20.1^{\mathrm{b}, \mathrm{c}}$ & NA & NA \\
\hline British Virgin Islands & 18,000 & $12.6^{c}$ & NA & NA \\
\hline
\end{tabular}

Abbreviation: BMI, body mass index; NA, information is not available.

a Wilson R. Ponte en forma: an assessment of the health needs of the population of Santa Cruz, Galapagos. August 2009 (unpublished data).

b Hosey et al (13).

c International Diabetes Federation (2).

d World Health Organization (10). 